\title{
ESTIMATION THE LOCATION PARAMETERS IN MOTION OF RADIO EMISSION SOURCE OF ELECTROMAGNETIC WAVE'S SPHERICAL FRONT
}

\author{
Evgeniy A. Yakornov, Oleg F. Tsukanov \\ "Igor Sikorsky Kyiv Polytechnic Institute", Kyiv, Ukraine
}

Background. Modern methods for determining the position of the source of radio emission in the Fresnel zone from the sphericity of the electromagnetic wave front received by the linear antenna array allow solving the problem of simultaneous determination of the direction and range only for a stationary source of radio emission. In the case of a radio source, the accuracy of estimating the location parameters will be low.

Objective. The aim of the paper is to increase the accuracy of the method for estimating the location parameters for a mobile radio source in the case of the sphericity of the electromagnetic wave front, which is adopted by a linear antenna array.

Methods. An estimate of the angular direction during the motion of a radio emission source is made by estimating the phase difference in the "sliding window". The range estimate is determined from the results of the estimates in the "sliding window" of the difference in phase differences between the symmetric elements of the linear array antenna.

Results. The considered method, based on the results of simulation, makes it possible to increase the accuracy for estimating the location parameters for a mobile radio source by $25-35 \%$.

Conclusions. The proposed method can be easily implemented in mobile monitoring systems of radio emission sources when they are in the Fresnel zone.

Key words: Fresnel zone; radio emission source; sphericity of the electromagnetic wave front; phase difference; difference of phase differences; linear array; sliding window; wavelength; estimation of location parameters.

\section{Introduction}

During the operation in the Fresnel zone [1] the errors of determining the radio emission sources (RES) location appear in the monitoring systems of radio emissions due to the sphericity (curvature) of the electromagnetic wave (EMW) fronts at the receiving side. Their reducing is overviewed in Refs $[1,2]$ as the solved problem of estimating the location of a stationary RES by measuring the difference in phase difference between several separated receiving antennas that accept an EMW with a spherical front. The accuracy of estimation the location parameters of the fixed RES is determined by the redundancy of the measurements, therefore in case of such RES moving, the dispersion of the estimation will increase.

We will consider a method of determining the RES location parameters for the Fresnel zone from the results of measuring phase shifts between the elements of the linear antenna array (AA), which will allow determining the location of the mobile source and improve the accuracy of locating the stationary one.

\section{Formulation of the research task}

Let the EMW with a spherical front enter the input AA consisting of $\mathrm{M}+1$ receiving antennas. The phase change at the input of the AA can be represented as [3]
$\varphi(L, \theta, r)=-k \cdot L \cdot \cos \theta+k \cdot\left(L^{2} / 2 \cdot r\right) \cdot \sin ^{2} \theta$

$+\left(L^{3} / 2 \cdot r^{2}\right) \cdot \cos \theta \cdot \sin ^{2} \theta+n(L, \theta, r)$

where $k=2 \pi / \lambda$ - wave number; $L$ - aperture width of AA, $\theta$ - bearing on RES; $r$ - distance to source; $n(L, \theta, r)$ - random phase fluctuations. Further limiting ourselves to the third order issues, the phase shift (1) at the AA input can be written as follows

$\varphi(L, \theta, r)=\Delta \varphi(L, \theta, r)+\Delta \Delta \varphi(L, \theta, r)+n(L, \theta, r) .(1 . a)$

In fomula (1.a), the first term $\Delta \varphi(L, \theta, r)$ is the phase shift due to the difference in the rays' path between the symmetric receiving antenna arrays and equals:

$\Delta \varphi(L, \theta, r)=-k \cdot L \cdot \cos \theta$

second term

$$
\Delta \Delta \varphi(L, \theta, r)=k \cdot L^{2} \cdot \sin ^{2} \theta / 2 \cdot r
$$

phase change due to the curvature of the phase front [5]. The curvature value $\alpha$ to the stationary RES by the sphericity of the EMW front is found from the results of the $\Delta \Delta \varphi(L, \theta, r)$ measurement, taking into account the errors of its measurement $n(L, \theta, r)$ from the fomula:

$$
\Delta \Delta \varphi(L, \theta, r)=G L^{2} \alpha+n(L, \theta, r)
$$

where $G=\left(k \cdot \sin ^{2} \theta\right) / 2 ; \alpha=1 / r$ - curvature (the value reversed to distance).

After sampling (3) for a constant bearing value $\theta$, we obtain:

$\overline{\Delta \Delta \varphi}(L, \alpha)=\bar{X}(L, \alpha)+\bar{n}(L)$

where $\bar{X}(L, \alpha)$ - the expected vector of the phase shift in the AA aperture due to the curvature of the phase front 
The estimation of the curvature $\hat{\alpha}$ under the condition of the normal law of error the phase measurement distribution $\bar{n}(L)$ with zero mathematical expectation $m_{\Delta \varphi}=0$ and the known dispersion $\sigma_{\Delta \varphi}^{2}$ can be represented based on the least squares method (LSM) in the following general form:

$\hat{\alpha}=\left(\bar{X}(L)^{T} \bar{X}(L)\right)^{-1} \bar{X}(L)^{T} \overline{\Delta \Delta \varphi}(L, \alpha)$,

where $\bar{X}(L)$ - expected signal, in vector form; $\overline{\mathrm{X}}(L)^{\mathrm{T}}=$ $G \mathrm{~L}^{2} / \mathrm{M}^{2} \mathrm{X}_{A P}^{\mathrm{T}}(L)$;

$$
\begin{gathered}
\overline{\mathrm{X}}(L)^{\mathrm{T}}=\left|\left(\frac{\mathrm{M}}{2}\right)^{2},\left(\frac{\mathrm{M}}{2}-1\right)^{2}, \ldots 1, . .\left(\frac{\mathrm{M}}{2}-1\right)^{2},\left(\frac{\mathrm{M}}{2}\right)^{2}\right| ; \\
\overline{\Delta \Delta \varphi}(L, \alpha)=\mid \Delta \Delta \varphi_{-\frac{\mathrm{M}}{2}}, \Delta \Delta \varphi_{-\frac{(\mathrm{M}-1)}{2}}, . \Delta \Delta \varphi_{-2}, \Delta \Delta \varphi_{1}, \\
\Delta \Delta \varphi_{2}, . . \Delta \Delta \varphi_{\frac{(\mathrm{M}-1)}{2}}, \Delta \Delta \varphi_{\frac{\mathrm{M}}{2}} \mid ;
\end{gathered}
$$

However, for practice it is more convenient to use the express for the estimation of the phase front curvature obtained in [4]:

$\hat{\alpha}=1 / r=\frac{15 M^{2} \sum_{i=1}^{\frac{M}{2}} i^{2} \Delta \Delta \varphi_{i}}{\left.G L^{2}(\mathrm{M} / 2)(\mathrm{M} / 2+1)(\mathrm{M}+1)\left[3(M / 2)^{2}\right]+3(\mathrm{M} / 2)-1\right]}$

where $\Delta \Delta \varphi_{i}=\Delta \varphi_{i}-\Delta \varphi_{-i}$ the difference of the phase differences between the symmetric elements relative to the central AA.

The dispersion of the error estimation $\hat{\alpha}$ $\sigma_{\alpha}^{2}=\left(\bar{X}(L)^{T} \bar{X}(L)\right)^{-1} \sigma_{\Delta \varphi}^{2}$,

taking into account the structure $X_{A P}(L)$

$\sigma_{\alpha}^{2}=90 \sigma_{\Delta \Delta \varphi}^{2} M^{4} /$

$\left.G L^{2}\left[3\left(\frac{M}{2}\right)^{2}+3\left(\frac{\mathrm{M}}{2}\right)-1\right)\right]\left(\frac{\mathrm{M}}{2}\right)(\mathrm{M} / 2+1)(\mathrm{M}+1)$.

To obtain the fomula for the estimation $\theta$, we use the ratio (2). In order to fact that $\Delta \varphi$ is related to $\theta$ by the cosine function, which is nonlinear, it is impossible to apply the classical LSM. However, if $\widehat{K}_{\theta}=\cos \hat{\theta}$ is taken as the estimated value, then fomula (2) becomes linear and then using the LSM with the representation $\bar{X}(L)^{T} \bar{X}(L)$ in the form of a row [5], we obtain fomulae for estimating $\widehat{K}_{\theta}$ and estimation dispersion $\sigma_{K_{\theta}}^{2}$ of the cosine bearing:

$$
\begin{aligned}
& \widehat{K}_{\theta}=-15 M^{2} \sum_{i=1}^{\frac{M}{2}} i^{2} \Delta \varphi_{i} / k L^{2}(\mathrm{M} / 2)(\mathrm{M} / 2+1) \\
& \left.(\mathrm{M}+1)\left[3(M / 2)^{2}\right]+3(\mathrm{M} / 2)-1\right] \\
& \sigma_{K_{\theta}}^{2}=90 \sigma_{\Delta \varphi}^{2} M^{4} / k L^{2}\left[3(M / 2)^{2}+3(\mathrm{M} / 2)-\right. \\
& 1](\mathrm{M} / 2)(\mathrm{M} / 2+1)(\mathrm{M}+1) .
\end{aligned}
$$

The weight vector $\mathrm{X}_{A P}^{\mathrm{T}}(L)$ shows that only the central antenna's AA signal is received without conversion, the others - with weights inversely proportional to the square of the antenna's number, from the left and right of the central antenna with a total number of $M+1$.

The estimation dispersion $\sigma_{\alpha}^{2}(8)$ is proportional to the measurement dispersion $\sigma_{\Delta \varphi}^{2}$ and decreases insignificantly while increasing the number of receiving antennas.

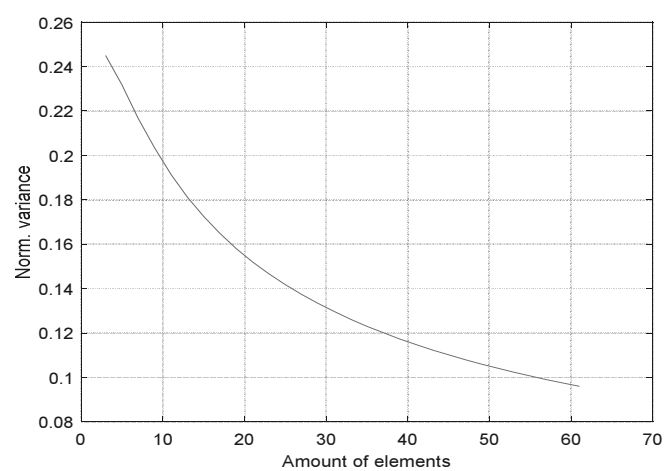

Fig.1. The dependence $\sigma_{\alpha}^{2}=1$ of $M$

It means that for immovable RES the decrease of the estimation dispersion $\sigma_{\alpha}^{2}$ can be achieved only due to the redundancy of the measurements $\overline{\Delta \Delta \varphi}(L, \alpha)$, namely by averaging the multiply obtained values $\hat{\alpha}$ by the number of measurements. On the basis of fomula (7) it can be concluded that while the RES moving, the dispersion $\sigma_{\Delta \varphi}^{2}$ will be determined by errors in the measurement of phase shifts only at the current time and therefore can not be reduced due to redundancy of the measurements themselves.

\section{Assessment of the parameters of the locations when moving RES}

Since the accuracy of the estimation of $\hat{\alpha}$ will decrease with the RES moving, the task of increasing, in our opinion, needs to be solved in two stages:

1) by analyzing the fomulae (2), (3), (6), (8) determine the conditions under which the values $\sigma_{\alpha}^{2}, \sigma_{K_{\theta}}^{2}$ can be reduced for a moving source;

2) to determine the steps sequence necessary to evaluate the parameters of the location when the RES moves.

To determine the conditions for decreasing of quantities $\sigma_{\alpha}^{2}, \sigma_{K_{\theta}}^{2}$, we consider fomulae (8) and (10), respectively. The $\sigma_{\alpha}^{2}$ depends on $\sigma_{\Delta \Delta \varphi}^{2}$, and $\sigma_{K_{\theta}}^{2}$ on $\sigma_{\Delta \varphi}^{2}$. The disperses $\sigma_{\Delta \varphi}^{2}$ and $\sigma_{\Delta \Delta \varphi}^{2}$ are determined by errors in the measurement of phase shifts $\Delta \varphi$. When the RES moves, the errors in the measurements of the phase shifts $\Delta \varphi$ will increase, hence the disperses of the errors $\sigma_{\Delta \varphi}^{2}$ and $\sigma_{\Delta \Delta \varphi}^{2}$ which means the same to accuracy of the estimation of the RES location parameters.

Therefore, in order to reduce the estimating location parameter errors $r, \theta$ it is necessary to reduce the error determination dispersion $\Delta \varphi$ и $\Delta \Delta \varphi$. The values $\sigma_{\Delta \varphi}^{2}$ and $\sigma_{\Delta \Delta \varphi}^{2}$ can be reduced by obtaining the estimates $\Delta \varphi$ and $\Delta \Delta \varphi$ taking into account the model of phase change in time and the sequence of measurement combination $\Delta \varphi_{t}, \Delta \varphi_{t-1}, \Delta \varphi_{t-2}, \ldots \Delta \varphi_{t-p} \quad$ и $\Delta \Delta \varphi_{t}$, $\Delta \Delta \varphi_{t-1}, \Delta \Delta \varphi_{t-2}, \ldots \Delta \varphi_{t-p}$ in some time, where $p$ is the width of the "sliding window" [6]. The complexity of the problem of estimating the RES location parameters according to the EMW front curvature $r, \theta$ is related to the impossibility of transforming fomulae (2) and (3) in the form of a linear dependence (7). In addition, it is possible to determine the values of the derivatives $\dot{r}, \dot{\theta}$ only by numerical differentiation. It should also be noted that the representation (2), (3) in the space of 
conditions would allow us to use the Kalman-Buci dynamic filter to solve the problem of estimating the location parameters [6]. That is why, the estimation of the location parameters during the RES movement will consist of two operations: the first one is the phase shift estimation, and the second one - the direct estimation of location parameters.

Changing the values $\Delta \varphi$ and $\Delta \Delta \varphi$ during the time $\left[t_{n-1}, t_{n}\right]$ while RES movement at the moment of time $t_{n}$ is possible to write down by the algebraic polynomial of $m$-degree

$$
\begin{aligned}
& \Delta \varphi_{t}=\Delta \varphi_{0}+\Delta \dot{\varphi}_{1}\left(t_{n}-t_{n-1}\right)+ \\
& 0.5 \Delta \ddot{\varphi}_{2}\left(t_{n}-t_{n-1}\right)^{2}+\ldots, \\
& \Delta \Delta \varphi_{t}=\Delta \Delta \varphi_{0}+\Delta \dot{\Delta \varphi_{1}}\left(t_{n}-t_{n-1}\right)+ \\
& 0.5 \Delta \ddot{\Delta} \varphi_{2}\left(t_{n}-t_{n-1}\right)^{2}+\ldots, .
\end{aligned}
$$

where $\Delta \varphi_{t}, \Delta \Delta \varphi_{t}$ - values of $\Delta \varphi \quad$ и $\Delta \Delta \varphi$ at the moment of time $t_{n}$;

$\dot{\Delta \varphi_{t}}, \Delta \Delta \varphi_{t}$ - first derivatives $\Delta \varphi$ and $\Delta \Delta \varphi$ at the moment of time $t_{n-1}$,

$\Delta \ddot{\varphi} t, \Delta \ddot{\Delta} \varphi_{t}-$ second derivatives $\Delta \varphi$ and $\Delta \Delta \varphi$ at the moment of time $t_{n-1}$.

The problem is to estimate the magnitude of the phase difference $\Delta \widehat{\varphi_{t}}$ by the set of the sequence $\Delta \varphi_{t}$, $\Delta \varphi_{t-1}, \Delta \varphi_{t-2}, \ldots . \Delta \varphi_{t-p}$, in accordance with model (11), and by the set of the sequence $\Delta \Delta \varphi_{t}, \Delta \Delta \varphi_{t-1}$, $\Delta \Delta \varphi_{t-2}, . . \Delta \Delta \varphi_{t-p}$ in accordance with (11.a), the estimation of difference in phase difference $\Delta \Delta \widehat{\varphi}_{t}$ is being obtaining. $\widetilde{\Delta \varphi}{ }_{t}$ и $\widetilde{\Delta \Delta \varphi}_{t}$ estimates will be found with the help of LSM in the "sliding window" For this, the model of the received signal phase changing during IRI motion is represented by a second-order polynomial:

$$
\begin{aligned}
& \Delta \varphi_{n}=a_{0}+a_{1} \Delta t+a_{2} \Delta t^{2} \\
& =b_{0}+b_{1} \Delta t+b_{2} \Delta t^{2}
\end{aligned}
$$

where $\Delta t=t_{n}-t_{n-1}$, coefficients $\mathrm{A}_{\Delta \varphi}{ }^{T}=\left|a_{0}, a_{1}, a_{2}\right|$ are analogs to $\Delta \varphi_{0}, \dot{\Delta \varphi_{1}}, \Delta \ddot{\varphi}_{2}$,

and have a physical meaning of the model (11), and $\mathrm{A}_{\Delta \Delta \varphi}{ }^{T}=\left|b_{0}, b_{1}, b_{2}\right|$ match to $\Delta \Delta \varphi_{0}, \Delta \dot{\Delta} \varphi_{1}, \Delta \ddot{\Delta} \varphi_{2}$ model (11a).

In the solution of the problem of estimating LSM, the choice of the time interval $\Delta t=t_{n}-t_{n-1}$ between the measurements $\Delta \varphi_{t}, \Delta \varphi_{t-1}, \Delta \varphi_{t-2}$...and $\Delta \Delta \varphi_{t}, \Delta \Delta \varphi_{t-1}, \Delta \Delta \varphi_{t-2}$. has a great importance, because the shorter time interval between measurements, the higher the estimation accuracy. The width of the "sliding window" $p$ is selected depending on the nature of the RES movement and it is obvious that the greater the speed and acceleration of the RES, the greater the value of $p$.
The vector of unknown coefficients in (12) can be represented as

$$
\mathrm{A}=\left(B^{T} \mathrm{~B}\right)^{-1} B^{T} F
$$

And further in accordance with (12), the values estimates $\widetilde{\Delta \varphi}_{t}$ и $\widetilde{\Delta \Delta \varphi}_{t}$ are calculated.

The second step, namely the sequence of steps for determining the position while the RES moving, based on the estimation of the phase difference $\Delta \varphi$ and the difference in phase differences $\Delta \Delta \varphi$ of the received signals, is as follows:

- the "sliding window" vector of the phase sequence of the received signals is forming:

$$
\Delta F_{p}=\left|\Delta \varphi_{t}, \Delta \varphi_{t-1}, \Delta \varphi_{t-2}, \ldots . \Delta \varphi_{t-p}\right| ;
$$

- the approximation coefficients $\mathrm{A}_{\Delta \varphi}$ of the vector $\widehat{\Delta \varphi}_{t}(13)$ are calculating;

- by the coefficients $\mathrm{A}_{\Delta \varphi}$, the estimate of the phase difference $\widehat{\triangle \varphi}_{t}(12)$ is determining;

- of the sequence of the phase differences is forming $\Delta \Delta F_{p}=\left|\Delta \Delta \varphi_{t}, \Delta \Delta \varphi_{t-1}, \Delta \Delta \varphi_{t-2}, \ldots . \Delta \Delta \varphi_{t-p}\right|$

- in accordance with (13), the approximation coefficients $\mathrm{A}_{\Delta \Delta \varphi}$ of the vector $\Delta \Delta F_{p}$;

- using the approximation coefficients $\mathrm{A}_{\Delta \Delta \varphi}$, the estimate of the difference of the phase differences ${\widehat{\Delta \Delta \varphi_{t}}}$ (13).

- the last elements $\Delta \varphi_{t-p}$ and $\Delta \Delta \varphi_{t-p}$ of the vectors $\Delta F_{p}$ and, respectively, $\Delta \Delta F_{p}$, are discarded, the remaining "shift to the right" to "empty places" the measured values $\Delta \varphi_{t}$, and $\Delta \Delta \varphi_{t}$ are recorded.

- in accordance with (9), the cosine of the bearing $\widehat{K}_{\theta}$ is determined;

- with the help of the fomula (6), the distance $\hat{r}$ is estimated.

The proposed method was investigated by the method of imitating the ensemble of input signals, obtained on the basis of the reference trajectory of RES moving between the near and far zones, $\left(R_{N z}=22 \mathrm{~m}\right.$., $R_{F Z}=480 \mathrm{~m}$ ) with the characteristics AA $\lambda=0.15 \mathrm{~m}, M$ $=40$ respectively and given errors statistical characteristics of phase shifts measurements of the received signals. The width of the "sliding window" $p=$ 10 provides the minimum mean-square error (MSE) of the estimation of $\hat{r}$ and $\hat{\theta}$. The centimeter-wavelength range is chosen to determine whether the proposed method can be used in portable devices of RES positioning.

The main results of the simulation are shown in Fig. 2-5. Fig. 2 shows the graphs of the changing $\overline{\Delta \Delta \varphi}$ measurement, $\Delta \Delta \varphi$ - standard, $\widehat{\Delta \Delta \varphi}$ - the difference in phase difference between the RES and the distance $r$ (the last two coincide). It is seen that as the range increases, the measurement errors $\overline{\Delta \Delta \varphi}$ increase. 


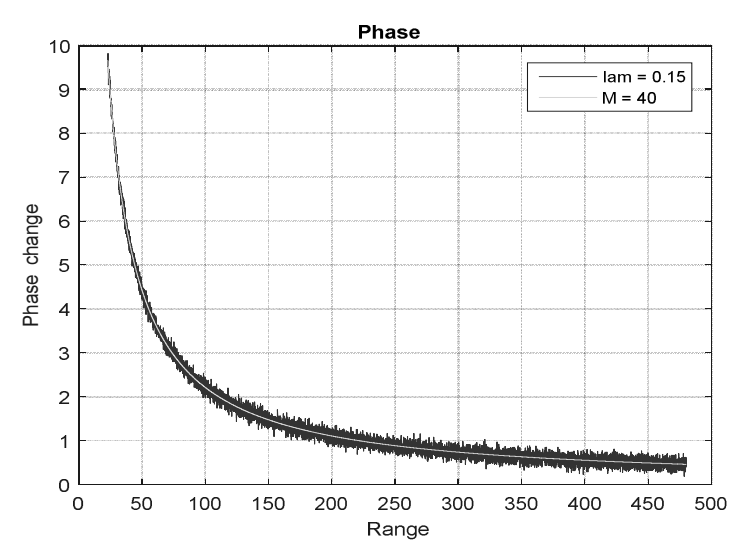

Fig.2. Changing $\overline{\Delta \Delta \varphi}, \Delta \Delta \varphi \overline{\Delta \Delta \varphi}$ from $r$.

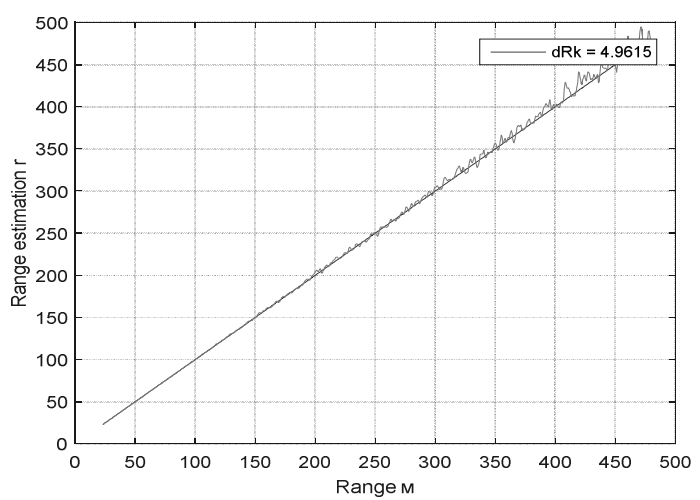

Fig. 4. Changing $\hat{r}$ from $r$ of proposed method.

Fig. 3 shows the trajectories: the standard $r$ and the range estimate $\hat{r}$ while moving RES within the near and far zone with a constant bearing value $\hat{\theta}$ of the method presented in [4].

Fig. 4 shows the trajectories: the standard $\hat{\theta}$ and the range estimates $\hat{r}$ while the RES movement within the near and far zone, obtained using the proposed method. The simulation results showed that the LSM of the range estimation on the entire RES motion path, with constant bearing, without estimation $\widetilde{\Delta \varphi}$ and $\overline{\Delta \Delta \varphi}$ is less than 5 meters, and with an estimate of less than 2 meters from the standard.

Comparison of the MSE estimations of $\widehat{r}$ obtained by averaging over the ensemble of input signals (Figure 5) allows us to state that the proposed method makes it possible to improve the accuracy of determining the location parameters by $25-35 \%$.

\section{Conclusions}

1. The analysis of a number of aspects of the RES positions determination based on the curvature of the front of received EMW during its motion in the Fresnel zone was made.

2. With constant bearing, the error in determining the RES location parameters depends on the distance

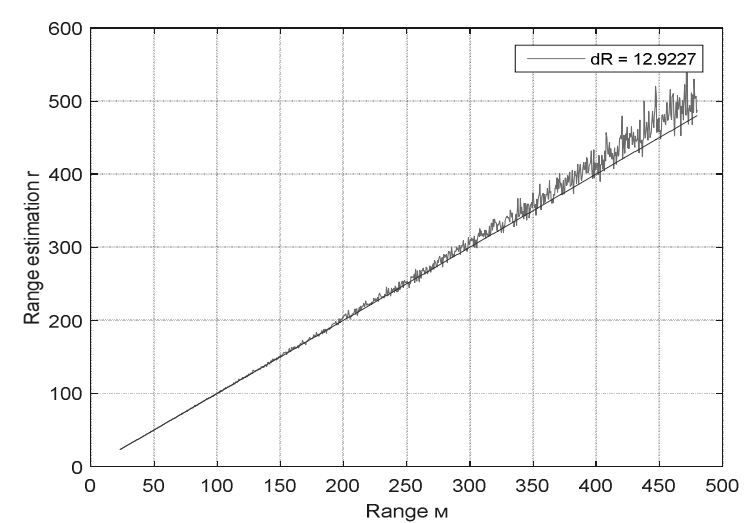

Fig.3. Changing $r$ and $\hat{r}$ the known method.

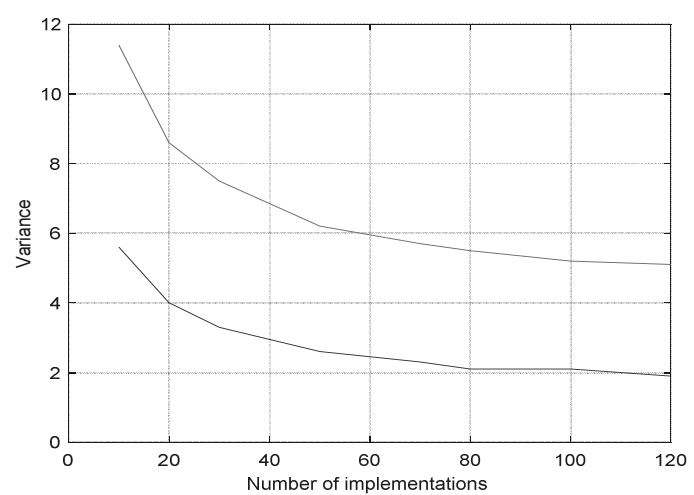

Fig. 5. Dependence MSE of estimation $\widehat{r}$ from the quantity of realizations.

estimation error. Moreover, the error of determining the range to RES is the greater the closer source to the far zone, which is associated with the growth of measurement errors in the phase difference of the received signals.

3. Estimation of the difference and the difference in the phase differences of the received signals makes it possible to improve the accuracy of determining the location parameters for both mobile and fixed RES.

4. The results obtained in the paper can be used in the design of RES multi-channel auto-tracking systems for their operation in the Fresnel zone.

\section{References}

[1] Avdeenko G., Fedorov I., Yakornov E. Determination of the source location of radio emission by the curvature of the front of the electromagnetic wave. Proceedings of universities. Radio electronics. - 2008. № 3. - p. 3-11.

[2] Avdeenko G., Lipchevska I., Yakornov E. Phase systems for determining the coordinates of the source of radio emission of a harmonic signal in the Fresnel zone. Proceedings of universities. Radioelectronics. 2012. № 2. - c. 24-33. 
[3] Tsukanov O., Yakornov E. A method for estimating the dynamic error in determining the distance to a source of radio emission by the sphericity of the electromagnetic wave front. // XI International Science and Technology Conference "Telecommunications Problems" (PT-17): Materials Conf. Kyiv, 18-21 April 2017 p. Kyiv, 2017. p.105-108.
[4] Patent № 2322681 (Russia) A method for determining the distance to the ejected interference transmitter and the device for its implementation. M. Cl. G01S 3/00 // Borovikov S., Yastrebov Y.

[5] Integrals and series. Prudnikov A., Brychkov Y., Marichev O. - M.: Science, 1981, p. 597.

[6] Kalmann-Bussi Filter. Bramer K., Zifling G.. - M.: Science,

1982 , 199

Якорнов Е.А., Цуканов О.Ф.

Оцінка параметрів місця розташування під час руху джерела радіовипрюмінювання для сферичного фронту електромагнітної хвилі

Проблематика. Сучасні методи визначення місця розташування джерела радіовипромінювання в зоні Френеля по сферичності фронту електромагнітної хвилі, що приймається лінійною антенною решіткою, дозволяють вирішувати задачу одночасного визначення напрямку і дальності тільки для нерухомого джерела радіовипромінювання В разі руху джерела радіовипромінювання точність оцінювання параметрів розташування буде невисокою.

Мета досліджень. Підвищення точності методу оцінки параметрів розташування для рухомого джерела радіовипромінювання в разі сферичності фронту електромагнітної хвилі яка приймається лінійною антенною решіткою.

Методика реалізації. Оцінка кутового напрямку при русі джерела радіовипромінювання проводиться шляхом оцінювання в "ковзному вікні" різниці фаз. Оцінка дальності визначається за результатами оцінок в "ковзному вікні" різниці різниць фаз між симетричними щодо центрального елементами лінійної антеною решітки.

Результати досліджень. Розглянутий метод за результатами імітаційного моделювання дозволяє підвищити точність оцінювання параметрів розташування для рухомого джерела радіовипромінювання на 25 $35 \%$.

Висновки. Запропонований метод може бути легко реалізований в мобільних системах моніторингу джерел радіовипромінювань при їх знаходженні в зоні Френеля

Ключові слова: зона Френеля; джерело радіовипромінювання; сферичність фронту електромагнітної хвилі; різниця фаз; різниця різниць фаз; лінійна антенна решітка; ковзне вікно; довжина хвилі; оцінка параметрів розташування.

\section{Якорнов Е.А., Цуканов О.Ф.}

Оценка параметров местоположения при движении источника радиоизлучения для сферического фронта электромагнитной волны

Проблематика. Современные методы определения местоположения источника радиоизлучения в зоне Френеля по сферичности фронта электромагнитной волны, принимаемой линейной антенной решеткой, позволяют решать задачу одновременного определения направления и дальности только для неподвижного источника радиоизлучения В случае движения источника радиоизлучения точность оценивания параметров местоположения будет невысокой.

Цель исследований. Повышение точности метода оценки параметров местоположения для подвижного источника радиоизлучения в случае сферичности фронта электромагнитной волны которая принимается линейной антенной решеткой.

Методика реализации. Оценка углового направления при движении источника радиоизлучения производится путем оценивания в "скользящем окне" разности фаз. Оценка дальности определяется по результатам оценок в "скользящем окне" разности разностей фаз между симметричными относительно центрального элементами линейной антенной решетки.

Результаты исследований. Рассмотренный метод по результатам имитационного моделирования позволяет повысить точность оценивания параметров местоположения для подвижного источника радиоизлучения на $25-35 \%$.

Выводы. Предложенный метод может быть легко реализован в мобильных системах мониторинга источников радиоизлучений при их нахождении в зоне Френеля

Ключевые слова: зона Френеля; источник радиоизлучения; сферичность фронта электромагнитной волны; разность фаз; разность разностей фаз; линейная антенная решетка; скользящее окно; длина волны; оценка параметров местоположения. 